Archived version from NCDOCKS Institutional Repository http://libres.uncg.edu/ir/asu/

\title{
Appalachlyan
}

B O O N E, NORT H C A R O L I A

\section{Magnetic susceptibility measurements to detect coal fly ash from the Kingston Tennessee spill in Watts Bar Reservoir}

\author{
Authors \\ Ellen A. Cowan, Keith C. Seramur, Steven J. Hageman
}

\begin{abstract}
An estimated $229000 \mathrm{~m} 3$ of coal fly ash remains in the river system after dredging to clean-up the 2008 Tennessee Valley Authority (TVA) spill in Kingston, Tennessee. The ash is heterogeneous with clear, orange and black spheres and non-spherical amorphous particles. Combustion produces iron oxides that allow low field magnetic susceptibility (cLF) and percent frequency dependent susceptibility (cFD\%) to be used to discriminate between coal fly ash and sediments native to the watershed. Riverbed samples with cLF greater than $3.0 \_10 \_6 \mathrm{~m} 3 / \mathrm{kg}$, have greater than $15 \%$ ash measured by optical point counting. cLF is positively correlated with total ash, allowing ash detection in riverbed sediments and at depth in cores. The ratio of ash sphere composition is altered by river transport introducing variability in cLF. Measurement of cLF is inexpensive, non-destructive, and a reliable analytical tool for monitoring the fate of coal ash in this fluvial environment
\end{abstract}

Ellen A. Cowan, Keith C. Seramur, Steven J. Hageman(2013) "Magnetic susceptibility measurements to detect coal fly ash from the Kingston Tennessee spill in Watts Bar Reservoir" Environmental Pollution v.174 pp. 179-188. Version Available at (www.journals.elsevier.com/environmental-pollution/) 


\title{
Magnetic susceptibility measurements to detect coal fly ash from the Kingston Tennessee spill in Watts Bar Reservoir
}

\author{
Ellen A. Cowan*, Keith C. Seramur, Steven J. Hageman \\ Department of Geology, Appalachian State University, Box 32067, Boone, NC 28608, USA
}

\begin{abstract}
An estimated $229000 \mathrm{~m} 3$ of coal fly ash remains in the river system after dredging to clean-up the 2008 Tennessee Valley Authority (TVA) spill in Kingston, Tennessee. The ash is heterogeneous with clear, orange and black spheres and non-spherical amorphous particles. Combustion produces iron oxides that allow low field magnetic susceptibility (CLF) and percent frequency dependent susceptibility (CFD\%) to be used to discriminate between coal fly ash and sediments native to the watershed. Riverbed samples with CLF greater than $3.0 \_10 \_6 \mathrm{~m} 3 / \mathrm{kg}$, have greater than $15 \%$ ash measured by optical point counting. CLF is positively correlated with total ash, allowing ash detection in riverbed sediments and at depth in cores. The ratio of ash sphere composition is altered by river transport introducing variability in CLF.

Measurement of CLF is inexpensive, non-destructive, and a reliable analytical tool for monitoring the fate of coal ash in this fluvial environment.
\end{abstract}

\section{Introduction}

The largest coal ash spill in US history occurred on December 22, 2008 at the Tennessee Valley Authority (TVA) coal-fired power plant in Kingston Tennessee. Approximately 4.1 million $\mathrm{m}^{3}$ (5.4 million cubic yards) of coal ash slurry was released onto the surrounding landscape by failure of $0.24 \mathrm{~km}^{2}$ (60 acres) of the 0.34 $\mathrm{km}^{2}$ (84-acre) ash storage complex (Tennessee Valley Authority, 2009). The adjacent Emory River channel was completely filled and the ash slurry extended $3.2 \mathrm{~km}$ (2 miles) upstream. By July 2011, most of the ash was removed from the Emory River by dredging, but about $229000 \mathrm{~m}^{3}$ (300 000 cubic yards) remain in the lower Emory River and downstream in the Clinch River (Carriker et al., 2011). Ash in the Clinch River has also been mixed with legacy sediments from Oak Ridge National Laboratory. In addition, up to $92000 \mathrm{~m}^{3}$ (120 000 cubic yards) of ash was remobilized and transported downstream from the spill site during a $1982 \mathrm{~m}^{3} / \mathrm{s}(70000 \mathrm{cfs})$ flow event that occurred in May 2009 (Scott and Zeller, 2011). The fate and effects of the residual ash is the long-term focus of the environmental studies associated with the TVA Kingston Fly Ash Recovery Project (Carriker et al., 2011).

This paper describes the application of magnetic susceptibility as an analytical tool to estimate the amount of ash in the riverbed after being transported and mixed with native river sediments. Detection of this ash is important because it is enriched in the trace elements strontium, arsenic, barium, and vanadium when compared with samples of soil in the vicinity of Kingston, TN (Ruhl et al., 2009). Metals adsorbed on the particle surfaces are easily mobilized into solution when fly ash is mixed and reacts with river water in the aquatic environment (Jankowski et al., 2006; Bednar et al., 2010). Pore water extracted from ash buried by river sediments exhibited parts-per-million levels of dissolved As, B, and $\mathrm{Sr}$ presenting a potential source of uptake to benthic infaunal organisms (Ruhl et al., 2010). Consequently, trace metals originating from coal fly ash can be passed up the food chain via dietary exposure (Bryan et al., 2012). Therefore, it is important to monitor the extent and distribution of the residual coal fly ash in the river system. This task is complicated by the location of the spill within the upper reaches of the Watts Bar Reservoir at approximately Emory River mile (ERM) 2.5 upstream of its confluence with the Clinch River (Fig. 1). TVA reported that ash was distributed upstream to ERM $6.0(9.6 \mathrm{~km})$ and downstream to Clinch River mile (CRM) 0.0 and from Tennessee River mile (TRM) 561.8 to TRM 568.7 (Ruhl et al., 2010). Also, the fluvial setting is influenced by the Watts Bar Dam, $71.8 \mathrm{~km}$ (44.6 miles) downstream of the spill, which has submerged the channels of the Emory and Clinch Rivers and adjacent stream terraces, many of which are seasonally exposed during low water.

Ferrimagnetic particulates in coal ash provide an opportunity to explore the application of magnetic methods to detect ash within the river sediment. Mass-specific magnetic susceptibility 


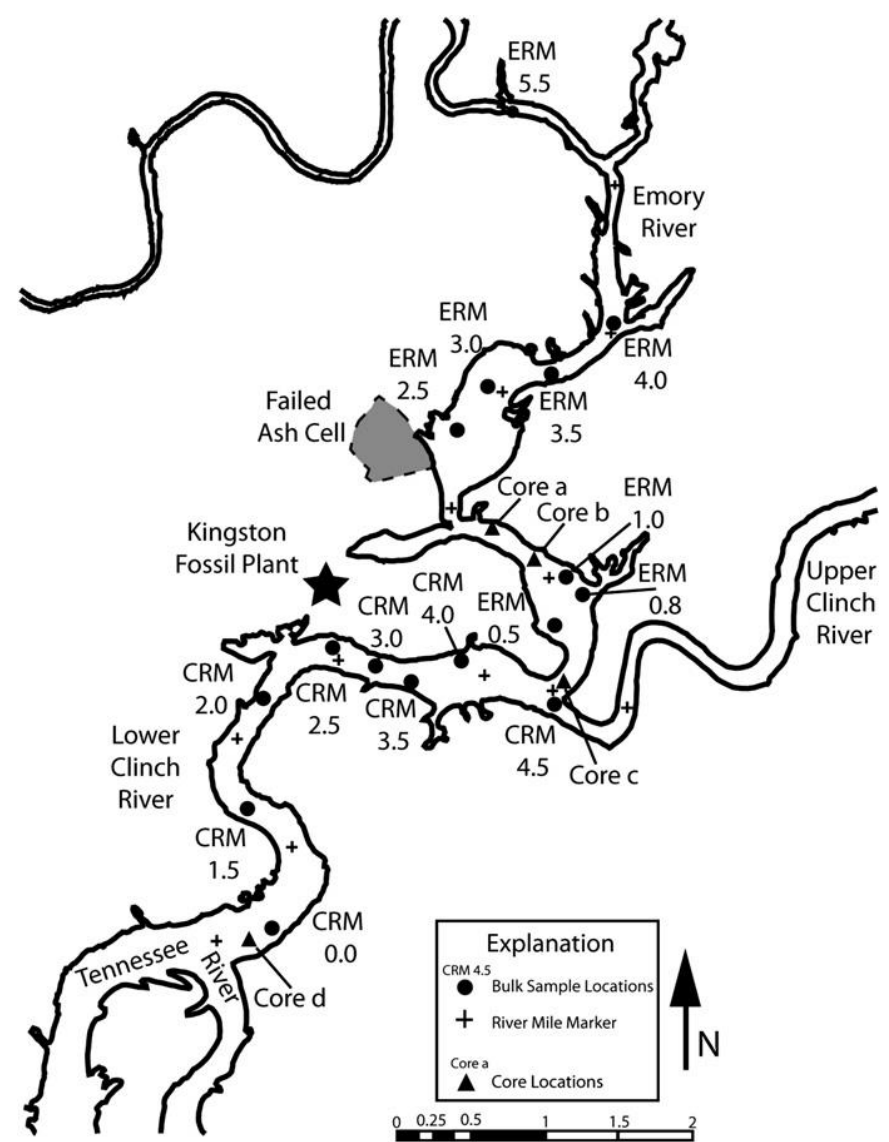

Fig. 1. Location map of sampling sites and the failed fly ash storage cell at TVA Kingston fossil plant, Tennessee.

(c) has been used as a proxy for the concentration of fly ash added in the manufacture of concrete (Presuel-Moreno and Sagüés, 2009) and it has been used to detect coal ash in the environment as airborne particles, as well as in soil, lake and river sediment (Flanders, 1994, 1999; Hanesch and Scholger, 2002; Magiera et al., 2002; Jordanova et al., 2004: Blundell et al., 2009; Li et al., 2011). Most unburned coal is non-magnetic, however the products of combustion can be rich in magnetite, as much as 500 to 10000 ppm by weight (Flanders, 1994). From 15 to 20 weight percent of fly ash from coal combustion is composed of magnetic iron oxides, including magnetite spherules (magnetospheres) (Chaddha and Seehra, 1983; Norton et al., 1986; Sokol et al., 2002; Zyryanov et al., 2011). Oxidation of the pyrite $\left(\mathrm{FeS}_{2}\right)$ in pulverized coal at high temperatures produces molten iron spheres and sulfur, the iron oxidizes to form magnetite $\left(\mathrm{Fe}_{3} \mathrm{O}_{4}\right)$ and hematite $\left(\mathrm{Fe}_{2} \mathrm{O}_{3}\right)$ as common constituents in fly ash (Flanders, 1994). Iron oxides in coal ash may occur in many forms, including dendritic patterns, both on the surface and within glassy aluminosilicate spheres (Norton et al., 1986; Booher et al., 1994; Jordanova et al., 2004; Kutchko and Kim, 2006). Some iron oxides have strong ferromagnetic or ferrimagnetic properties allowing ash, even in minor amounts, to be detected by magnetic susceptibility measurements which depend on the abundance and grain size of these minerals (Thompson and Oldfield, 1986; Verosub and Roberts, 1995). Mass-specific magnetic susceptibility (c) can be an effective environmental tracer because measurements are made on bulk sediment samples without pretreatment, resulting in a rapid, nondestructive, reliable, and relatively inexpensive analytical method when compared with chemical analyses (Verosub and Roberts, 1995; Petrovský et al., 2000).
1.1. Magnetic susceptibility and the geologic setting of the Emory and Clinch River watersheds

The effectiveness of using $C$ as a tool for tracking concentrations and movement of coal ash in river systems depends on the contrast between magnetic characteristics of native river sediments and coal fly ash. The bulk $C$ of native river sediment is the sum of the proportional contributions of $\mathrm{C}$ for each mineral present in those sediments. Ferromagnetic minerals such as magnetite and maghemite carry the strongest magnetic signal with additional contributions from canted anti-ferromagnetic iron minerals such as hematite (Dearing, 1999; Petrovský et al., 2000). Weaker C values from paramagnetic minerals such as clay minerals and pyrite also contribute to the bulk native sediment $\mathrm{C}$, but to a lesser extent. Ferromagnetic solids can produce magnetizations orders of magnitude larger than paramagnetic solids (Butler, 1992). Minerals such as quartz and calcite are diamagnetic meaning they produce weak or negative values of $\mathrm{C}$, thus do not contribute significantly to the magnetic signal of bulk sediments.

The Emory River Watershed is approximately $2260 \mathrm{~km}^{2}$ $\left(872 \mathrm{mi}^{2}\right)$ and drains to the Clinch River embayment of the upper Watts Bar Reservoir. The Cumberland Plateau, which includes conglomerate, sandstone, siltstone, and shale, comprises over $80 \%$ of the watershed (TDEC, 2002). Predominant rock types in the other physiographic provinces in the watershed include limestone, dolomite, and coal. These sedimentary rocks are not a typical source of magnetite, the principal mineral carrier of $\mathrm{C}$ (Dearing, 1999). These rocks would more likely contribute hematite and paramagnetic minerals to the fluvial sediment load. Since $C$ of hematite is two to three orders of magnitude smaller than that of magnetite, the effect of hematite in the presence of magnetite in fly ash is negligible (Presuel-Moreno and Sagüés, 2009).

The Clinch River originates in the mountains of southwestern Virginia, however its sediment load is captured by Norris Lake before it enters the Lower Clinch River watershed (TDEC, 2006). Rocks in the Lower Clinch River watershed are mostly limestone, dolomite, and shale (TDEC, 2006). These rocks are also expected to supply a sediment load with a lower $C$. In addition, the terminal size range of heavy minerals is within the fine sand size-class $(0.25 \mathrm{e}$ $0.10 \mathrm{~mm}$; Dreimanis and Vagners, 1971) so much of the naturally occurring magnetite is trapped by dams on the Clinch River before reaching the confluence of the Emory River.

The contrast between the $C$ of the ferromagnetic fly ash and that of the native sediment in the Clinch and Emory Rivers is large, which makes magnetic susceptibility useful as a tracer of coal fly ash in this system. In this field-based study we tested the ability of $C$ to detect the amount of coal fly ash within the riverbed. In addition, we describe the physical characteristics of the coal fly ash collected from an intact storage cell at the Kingston Fossil plant (Standard ash) and we discuss the contributions of different components of the ash to the bulk C signature. Finally, we demonstrate the ability of $C$ to detect ash in the sedimentary record from a series of cores collected downstream from the ash spill.

\section{Methods}

\subsection{Field sampling}

Samples measured for $\mathrm{C}$ were collected from the riverbed using box corers, vibra-cores, and gravity cores over a 2-year time span between June 2009 and May 2011. Samples collected by box corers, which penetrate sediments to a maximum depth of $15 \mathrm{~cm}$, were homogenized to produce representative near-surface riverbed sediment samples. Samples from vibracorers and gravity corers, which penetrate to greater depths, were split along their lengths, photographed, and described, then subsamples representing each sediment type were collected. 
Table 1

C, $\mathrm{CFd}_{\mathrm{Fd}} \%$ and point counts of three jars of Standard fly ash. One cube was measured for $\mathrm{C}_{\mathrm{LF}}$ for one sample jar but four slides (AeD) were prepared and counted. Diameters of ash spheres were measured from these microscope slides. For two other jars two cubes were packed and three slides were made and counted.

\begin{tabular}{|c|c|c|c|c|c|c|c|c|c|c|c|}
\hline TVA Sample ID & Lab ID & $\mathrm{C}_{\mathrm{LF}} \mathrm{m}^{3} / \mathrm{kg}$ & $\mathrm{C}_{\mathrm{FD}} \%$ & $\begin{array}{l}\text { Total ash } \\
\text { spheres (\%) }\end{array}$ & $\begin{array}{l}\text { Clear ash } \\
\text { spheres (\%) }\end{array}$ & $\begin{array}{l}\text { Average clear } \\
\text { ash sphere } \\
\text { diameter }(\mathrm{mm})\end{array}$ & $\begin{array}{l}\text { Black ash } \\
\text { spheres (\%) }\end{array}$ & $\begin{array}{l}\text { Average black } \\
\text { ash sphere } \\
\text { diameter }(\mathrm{mm})\end{array}$ & $\begin{array}{l}\text { Orange ash } \\
\text { spheres (\%) }\end{array}$ & $\begin{array}{l}\text { Average orange } \\
\text { ash sphere } \\
\text { diameter }(\mathrm{mm})\end{array}$ & $\begin{array}{l}\text { Non spherical } \\
\text { ash }(\%)\end{array}$ \\
\hline KIF-PE_ASH-CA-122208 & Fly Ash A & $5.40 \mathrm{E}-06$ & & 44.2 & 30.6 & 5.22 & 5.3 & 8.59 & 8.3 & 9.73 & 55.8 \\
\hline KIF-PE_ASH-CA-122208 & Fly Ash B & $5.40 \mathrm{E}-06$ & & 48.2 & 32.3 & 6.13 & 4.6 & 9.82 & 11.3 & 9.58 & 51.8 \\
\hline KIF-PE_ASH-CA-122208 & Fly Ash C & $5.40 \mathrm{E}-06$ & & 56.9 & 49.3 & 5.23 & 2.6 & 8.29 & 5.0 & 9.74 & 43.1 \\
\hline KIF-PE_ASH-CA-122208 & Fly Ash D & $5.40 \mathrm{E}-06$ & & 56.2 & 45.6 & 3.85 & 3.6 & 7.72 & 7.0 & 8.93 & 43.8 \\
\hline KIF-PE_ASH_CA-122208-3-5-F & Ash 1-1 & $4.99 \mathrm{E}-06$ & 1.4 & 54.5 & 49 & e & 1 & e & 4.3 & e & 45.5 \\
\hline KIF-PE_ASH_CA-122208-3-5-F & Ash 1-2 & $4.31 \mathrm{E}-06$ & 1.4 & 48.6 & 42 & e & 3.6 & e & 3 & e & 51.4 \\
\hline KIF-PE_ASH_CA-122208-3-5-F & Ash 1-3 & e & e & 58.6 & 54 & e & 2.6 & e & 2 & e & 41.4 \\
\hline KIF-PE_ASH_CA-122208-3-8-1 & Ash 2-1 & $4.33 \mathrm{E}-06$ & 1.4 & 46.9 & 39.3 & e & 3 & e & 4.6 & e & 53.1 \\
\hline KIF-PE_ASH_CA-122208-3-8-1 & Ash 2-2 & $4.31 \mathrm{E}-06$ & 1.3 & 41.3 & 37.3 & e & 1 & e & 3 & e & 58.7 \\
\hline KIF-PE_ASH_CA-122208-3-8-1 & Ash 2-3 & e & e & 43.6 & 37 & e & 2.3 & e & 4.3 & e & 56.4 \\
\hline Average Values & & & & 49.9 & 41.6 & 5.11 & 3.0 & 8.61 & 5.3 & 9.49 & 50.1 \\
\hline
\end{tabular}

Table 2

Samples point counted and measured for $C_{L F}$. Three groups are identified from $C_{L F}$ (Fig. 3a), including group 1a and $1 \mathrm{~b}$ with low $C_{L F}$ and group 2 , which includes samples from the spill with $>15 \%$ ash.

\begin{tabular}{|c|c|c|c|c|c|c|c|c|c|c|c|}
\hline Group & ASU lab ID & Data set & $\begin{array}{l}\text { Magnetic susceptibility } \\
\mathrm{LF}\left(\mathrm{m}^{3} / \mathrm{kg}\right)\end{array}$ & $\begin{array}{l}\text { Frequency } \\
\text { dependence }\end{array}$ & $\begin{array}{l}\text { Total ash } \\
\text { spheres (\%) }\end{array}$ & $\begin{array}{l}\text { Clear ash } \\
\text { spheres }(\%)\end{array}$ & $\begin{array}{l}\text { Black ash } \\
\text { spheres (\%) }\end{array}$ & $\begin{array}{l}\text { Orange ash } \\
\text { spheres (\%) }\end{array}$ & $\begin{array}{l}\text { Mineral } \\
\text { grains (\%) }\end{array}$ & $\begin{array}{l}\text { Organic } \\
\text { matter }(\%)\end{array}$ & $\begin{array}{l}\text { Core depth } \\
\text { (cm) }\end{array}$ \\
\hline $1 \mathrm{a}$ & ERM1-L9-C2-\#32 & ASU & $1.97 \mathrm{E}-07$ & 7.6 & 1.3 & 1.3 & 0.0 & 0.0 & 98.0 & 0.6 & 39 \\
\hline $1 \mathrm{a}$ & $\mathrm{t} 2-1$ tva 2 & ASU & $2.83 \mathrm{E}-07$ & 8.2 & 0.3 & 0.3 & 0.0 & 0.0 & 99.6 & 0.0 & e \\
\hline $1 \mathrm{a}$ & ERM1-L9-C1-\#21 & ASU & $4.42 \mathrm{E}-07$ & 6.3 & 0.3 & 0.3 & 0.0 & 0.0 & 99.6 & 0.0 & 43 \\
\hline $1 \mathrm{a}$ & CRMO-L3-BeC1-\#37 & ASU & $4.87 \mathrm{E}-07$ & 7.1 & 0.6 & 0.6 & 0.0 & 0.0 & 98.3 & 1.0 & 44 \\
\hline $1 \mathrm{a}$ & ERM1-L3-C1-\#63 & ASU & $4.95 \mathrm{E}-07$ & 3.7 & 0.3 & 0.3 & 0.0 & 0.0 & 99.6 & 0.0 & 98 \\
\hline $1 \mathrm{a}$ & EMORY REF B & Bulk & $1.70 \mathrm{E}-07$ & 7.5 & 0.0 & 0.0 & 0.0 & 0.0 & 94.6 & 5.3 & e \\
\hline $1 \mathrm{a}$ & CLINCH REF B & Bulk & $3.86 \mathrm{E}-07$ & 3.6 & 0.0 & 0.0 & 0.0 & 0.0 & 99.6 & 0.3 & e \\
\hline $1 \mathrm{~b}$ & ERMO-L2-C2-\#16 & ASU & $7.00 \mathrm{E}-07$ & 6.4 & 2.2 & 1.3 & 0.6 & 0.3 & 97.6 & 0.0 & 54 \\
\hline $1 \mathrm{~b}$ & e3-2 tva5 & ASU & $1.01 \mathrm{E}-06$ & 1.9 & 4.2 & 3.6 & 0.6 & 0.0 & 95.3 & 0.3 & e \\
\hline $1 \mathrm{~b}$ & ERMO-L2-C2-\#15 & ASU & $1.02 \mathrm{E}-06$ & 3.8 & 2.6 & 2.6 & 0.0 & 0.0 & 97.3 & 0.0 & 38 \\
\hline $1 \mathrm{~b}$ & CRMO-L3-A-C1-\#34 & ASU & $1.21 \mathrm{E}-06$ & 3 & 0.9 & 0.6 & 0.3 & 0.0 & 99.0 & 0.0 & 30 \\
\hline $1 \mathrm{~b}$ & CRMO-L3-A-C1-\#33 & ASU & $1.50 \mathrm{E}-06$ & 4.3 & 5.6 & 4.0 & 1.3 & 0.3 & 94.3 & 0.0 & 6 \\
\hline $1 \mathrm{~b}$ & CRMO-L3-BeC1-\#38 & ASU & $1.73 \mathrm{E}-06$ & 1.7 & 2.6 & 1.6 & 1.0 & 0.0 & 97.3 & 0.0 & 55 \\
\hline $1 \mathrm{~b}$ & CRMO-L3-A-C1-\#35 & ASU & $1.75 \mathrm{E}-06$ & 3.7 & 0.6 & 0.6 & 0.0 & 0.0 & 99.3 & 0.0 & 50 \\
\hline $1 \mathrm{~b}$ & ERM $4.0 \mathrm{~B}$ & Bulk & $7.60 \mathrm{E}-07$ & 3.9 & 1.3 & 1.0 & 0.3 & 0.0 & 96.6 & 2.0 & e \\
\hline $1 \mathrm{~b}$ & ERM 5.5 B & Bulk & $1.35 \mathrm{E}-06$ & 3.1 & 7.2 & 5.6 & 1.0 & 0.6 & 87.0 & 5.6 & e \\
\hline $1 \mathrm{~b}$ & CRM $1.5 \mathrm{C}$ & Bulk & $2.24 \mathrm{E}-06$ & 2.8 & 4.6 & 3.0 & 1.3 & 0.3 & 95.0 & 0.3 & e \\
\hline 2 & t1-2 tva11 & ASU & $3.85 \mathrm{E}-06$ & 2.3 & 25.9 & 20.6 & 3.3 & 2.0 & 73.3 & 0.6 & e \\
\hline 2 & ERM1-L9-C2-\#30 & ASU & $4.03 \mathrm{E}-06$ & 2.4 & 50.9 & 43.0 & 3.6 & 4.3 & 49.0 & 0.0 & 12 \\
\hline 2 & ERM1-L9-C1-\#19 & ASU & $4.03 \mathrm{E}-06$ & 2.1 & 37.5 & 28.6 & 5.6 & 3.3 & 61.6 & 0.6 & 20 \\
\hline 2 & ERM1-L3-C1-\#58 & ASU & $5.20 \mathrm{E}-06$ & 1.6 & 55.6 & 38.0 & 12.0 & 5.6 & 43.3 & 1.0 & 35 \\
\hline 2 & CRMO-L3-BeC1-\#36 & ASU & $5.33 \mathrm{E}-06$ & 1.6 & 30.2 & 22.6 & 5.3 & 2.3 & 69.0 & 0.6 & 8.5 \\
\hline 2 & ERM1-L3-C1-\#62 & ASU & $5.59 \mathrm{E}-06$ & 1 & 48.0 & 36.0 & 8.0 & 4.0 & 52.0 & 0.0 & 84 \\
\hline 2 & ERM1-L3-C1-\#56 & ASU & $6.27 \mathrm{E}-06$ & 2.7 & 45.5 & 32.6 & 9.6 & 3.3 & 54.3 & 0.0 & 10 \\
\hline 2 & ERM1-L9-C2-\#29 & ASU & $6.43 \mathrm{E}-06$ & 1 & 42.2 & 34.6 & 6.0 & 1.6 & 56.3 & 1.3 & 2.5 \\
\hline 2 & ERM1-L3-C1-\#61 & ASU & $6.44 \mathrm{E}-06$ & 0.9 & 36.8 & 25.6 & 7.6 & 3.6 & 63.0 & 0.0 & 65 \\
\hline 2 & ERM1-L9-C2-\#31 & ASU & $6.60 \mathrm{E}-06$ & 0.5 & 60.6 & 45.3 & 8.0 & 7.3 & 39.0 & 0.3 & 19 \\
\hline 2 & ERM1-L3-C1-\#59 & ASU & $6.76 \mathrm{E}-06$ & 1.6 & 52.8 & 32.6 & 10.6 & 9.6 & 46.6 & 0.3 & 48 \\
\hline 2 & ERMO-L2-C2-\#12 & ASU & 7.70E-06 & 0.6 & 17.9 & 13.3 & 3.3 & 1.3 & 80.0 & 2.0 & 8 \\
\hline 2 & ERM1-L3-C1-\#57 & ASU & $8.02 \mathrm{E}-06$ & 2 & 57.9 & 33.3 & 14.0 & 10.6 & 42.0 & 0.0 & 21 \\
\hline 2 & e1-3 tva15 & ASU & 8.98E-06 & 1.6 & 22.6 & 14.6 & 4.0 & 4.0 & 75.0 & 2.3 & e \\
\hline 2 & ERM1-L9-C1-\#20 & ASU & $9.38 \mathrm{E}-06$ & 0.8 & 52.6 & 39.6 & 8.0 & 5.0 & 47.3 & 0.0 & 32 \\
\hline 2 & ERMO-L2-C2-\#13 & ASU & $9.83 \mathrm{E}-06$ & 0.5 & 34.6 & 23.6 & 9.0 & 2.0 & 64.3 & 1.0 & 22 \\
\hline 2 & ERM0-L2-C2-\#14 & ASU & $9.96 \mathrm{E}-06$ & 1.1 & 52.2 & 40.0 & 7.6 & 4.6 & 46.3 & 1.3 & 29.5 \\
\hline 2 & ERM1-L9-C1-\#18 & ASU & $1.07 \mathrm{E}-05$ & 0.1 & 40.0 & 18.0 & 15.0 & 7.0 & 60.0 & 0.0 & 13.5 \\
\hline 2 & e1-1 tva 17 & ASU & $1.14 \mathrm{E}-05$ & 1.5 & 36.9 & 27.3 & 7.6 & 2.0 & 63.0 & 0.0 & e \\
\hline 2 & ERM1-L3-C1-\#60 & ASU & $1.31 \mathrm{E}-05$ & 0.4 & 50.9 & 35.3 & 10.6 & 5.0 & 49.0 & 0.0 & 56 \\
\hline 2 & CRM $4.5 \mathrm{~B}$ & Bulk & $3.84 \mathrm{E}-06$ & 2.3 & 18.9 & 15.6 & 2.3 & 1.0 & 80.6 & 0.3 & e \\
\hline 2 & CRM $2.5 \mathrm{~B}$ & Bulk & $4.49 \mathrm{E}-06$ & 1.9 & 22.5 & 10.6 & 9.6 & 2.3 & 75.6 & 1.9 & e \\
\hline 2 & CRM $4.0 \mathrm{~B}$ & Bulk & $5.60 \mathrm{E}-06$ & 1.9 & 24.2 & 17.6 & 4.6 & 2.0 & 74.0 & 1.6 & e \\
\hline 2 & CRM $3.5 \mathrm{~B}$ & Bulk & $5.80 \mathrm{E}-06$ & 1.8 & 24.9 & 17.6 & 4.3 & 3.0 & 73.0 & 2.0 & e \\
\hline 2 & CRM $2.0 \mathrm{~B}$ & Bulk & $5.97 \mathrm{E}-06$ & 1.2 & 32.2 & 18.6 & 7.3 & 6.3 & 67.3 & 0.3 & e \\
\hline 2 & CRM $0.0 \mathrm{C}$ & Bulk & $6.34 \mathrm{E}-06$ & 1.7 & 18.5 & 12.6 & 3.3 & 2.6 & 80.0 & 1.3 & e \\
\hline 2 & CRM $3.0 \mathrm{C}$ & Bulk & $6.92 \mathrm{E}-06$ & 1 & 18.9 & 9.3 & 5.3 & 4.3 & 79.0 & 2.0 & e \\
\hline 2 & ERM $3.5 \mathrm{~B}$ & Bulk & $7.18 \mathrm{E}-06$ & 1.4 & 41.2 & 19.6 & 12.3 & 9.3 & 58.6 & 0.0 & e \\
\hline 2 & ERM $3.0 \mathrm{C}$ & Bulk & $7.63 \mathrm{E}-06$ & 1.2 & 27.9 & 20.0 & 4.3 & 3.6 & 70.3 & 1.6 & e \\
\hline 2 & ERM $0.8 \mathrm{C}$ & Bulk & 7.63E-06 & 1.4 & 27.9 & 20.0 & 4.6 & 3.3 & 70.0 & 2.0 & e \\
\hline 2 & ERM $1.0 \mathrm{~B}$ & Bulk & 8.07E-06 & 1.5 & 42.9 & 29.6 & 9.0 & 4.3 & 55.3 & 1.8 & e \\
\hline 2 & ERM 0.5 B & Bulk & $8.50 \mathrm{E}-06$ & 1.1 & 38.2 & 24.0 & 7.6 & 6.6 & 60.0 & 1.8 & e \\
\hline 2 & ERM $2.5 \mathrm{C}$ & Bulk & $9.29 \mathrm{E}-06$ & 1.9 & 59.9 & 42.3 & 11.0 & 6.6 & 40.0 & 0.0 & e \\
\hline
\end{tabular}


Three 4-oz jars of "Standard ash" were provided by TVA for analysis. These samples were prepared from approximately 50 gallons of ash collected on March 10 , 2009 from the surface of the intact ash storage cell remaining in place after the spill. The collected ash was homogenized at the TVA lab in Muscle Shoals, AL using a polymer-body cement mixer. The large sample was air dried, then repeatedly and systematically mixed in batches over a 3 -day period before being split into quart jars and then randomly split into $4^{-\mathrm{oz}}$ jars (Personal communication, William Rogers, 2012).

\subsection{C measurements}

Frequency dependent mass-specific magnetic susceptibility (c) was measured at low $\left(\mathrm{k}_{\mathrm{LF}} 0.46 \mathrm{KHz}\right)$ and high $\left(\mathrm{k}_{\mathrm{HF}} 4.6 \mathrm{KHz}\right)$ frequencies using a Bartington Instruments MS-3 meter with a dual frequency MS2B sensor on dry sediment packed into $6.02 \mathrm{~cm}^{3}$ plastic cubes. The volume specific magnetic susceptibility values $(k)$ were converted into mass specific susceptibility (c) to account for different sample densities. The volume magnetic susceptibility $(k)$ is divided by the bulk density of the sample to obtain a mass specific magnetic susceptibility expressed in units of $\mathrm{m}^{3} / \mathrm{kg}$ (Dearing, 1999). Percent frequency dependent magnetic susceptibility (CFD\%) is calculated as: $\mathrm{C}_{\mathrm{FD}} \% 1 / 4\left[\left(\mathrm{C}_{\mathrm{LF}}-\mathrm{C}_{\mathrm{HF}}\right) / \mathrm{C}_{\mathrm{LF}}\right] \times 100$. A high $\mathrm{C}_{\mathrm{FD}} \%$ indicates the presence of ultrafine $(<0.03 \mathrm{~mm})$ superparamagnetic grains (Dearing, 1999), whereas fly ash typically has low CFD\% (Magiera et al., 2011). Superparamagnetic grains occur as crystals produced by biological and pedological processes in soils or in reducing environments such as lake sediments.

\subsection{Determination of percent ash spherules by point counting}

Previous studies of coal fly ash report that usually both magnetic minerals and trace metals are concentrated in spherical ash particles (Chaddha and Seehra, 1983; Norton et al., 1986; Wadge et al., 1986; Querol et al., 1994; Magiera et al., 2011). Ash spheres can also be visually identified when mixed with minerals in riverbed samples. To estimate the amount of spherical ash in samples measured for $C$ the percent spherical ash was point counted using a Leica DMLP polarizing microscope with a Swift model F automated point counter. Smear slides were made by taking a small amount of dry sample from the plastic cube and distributing it in a drop of distilled water across a $27 \mathrm{~mm} \times 49 \mathrm{~mm}$ glass slide. Upon drying, the sample was permanently mounted under a coverslip with epoxy having a refractive index of 1.520 (Locktite Impruv 363).

Most slides were counted under 200x magnification. The automatic stage advanced w18 mm with every click and three evenly spaced rows were counted per slide to reach 300 counts. Only particles that fell under the crosshairs were counted following the protocol established for TVA by RJ Lee Group (2010). Each particle was assigned to one of five categories; "clear" ash spheres (colorless or with a blue tint), black ash spheres (opaque), orange ash spheres (with an orange hue), mineral grains, and organic matter. Mineral grains included clay-size particles as well as non-spherical silt and sand grains. Organic matter included both terrestrial plant fragments as well as freshwater microfossils, mostly diatoms. If the crosshairs landed on an empty space or if the particle could not be assigned to one of the above groups, it was skipped and the stage was advanced to the next point. The point counts were based on a small subsample that should be representative of the cube if the sample is well mixed. We tested the reproducibility of our slide making and point counting by preparing and counting multiple sides from a group of 18 Bulk samples described below in Section 2.4. Two slides were counted for each sample and if the total ash counts differed by more than $10 \%$ a third slide was made and counted. One representative sample was then used to represent the \% spherical ash in the cube.

Standard ash samples were point counted following the same protocol except that each sample included the three types of ash spherules and a fourth category termed non-spherical ash. The diameter of clear, black, and orange ash spheres were measured on 50 points of each type observed in digital images taken with a microscope-mounted camera (Table 1)

\subsection{Data sets used in this study}

The relation between the occurrence of ash and $C$ was developed from a set of 58 samples that included eight Standard ash samples collected from the intact storage cell (Table 1) and 50 samples from the riverbed (Table 2). Eighteen of the riverbed samples are referred to as Bulk samples (Fig. 1). These were subsamples from an w 30 gallon composite sample of several box cores systematically collected and homogenized in polyethylene barrels from the same general location identified by river mile. The Bulk samples were collected from nine Emory River locations on May 23e24, 2011 and nine Clinch River locations on February 7e8, 2011. Two of these samples were collected upstream of the spill on the Emory and Clinch Rivers and are labeled Reference samples (REF). The remaining 32 , referred to as ASU samples were from individual box cores and subsamples from longer sediment cores collected between 2009 and 2011 (Table 2).

\section{Results and interpretation}

\subsection{Morphology of Standard ash samples}

Samples from the storage cell contained from 44 to 59 percent ash spheres, with the rest composed of non-spherical ash (Table 1). These ash particles are similar to those described from a typical fly ash from Eastern U.S. coal combustion that includes spherical particles in an amorphous matrix (Fisher et al., 1976). The specific composition of fly ash depends on the physical and chemical properties of the coal, the burning process and type of ash collector (Jankowski et al., 2006). For example, fewer spheres relative to amorphous material may indicate a lower boiler temperature and incomplete combustion resulting in a greater proportion of unburned carbon (Booher et al., 1994; Fisher et al., 1978). Optical images of spherical ash from the Standard ash samples included many small clear spheres (average diameter of $5 \mathrm{~mm}$ ), and fewer

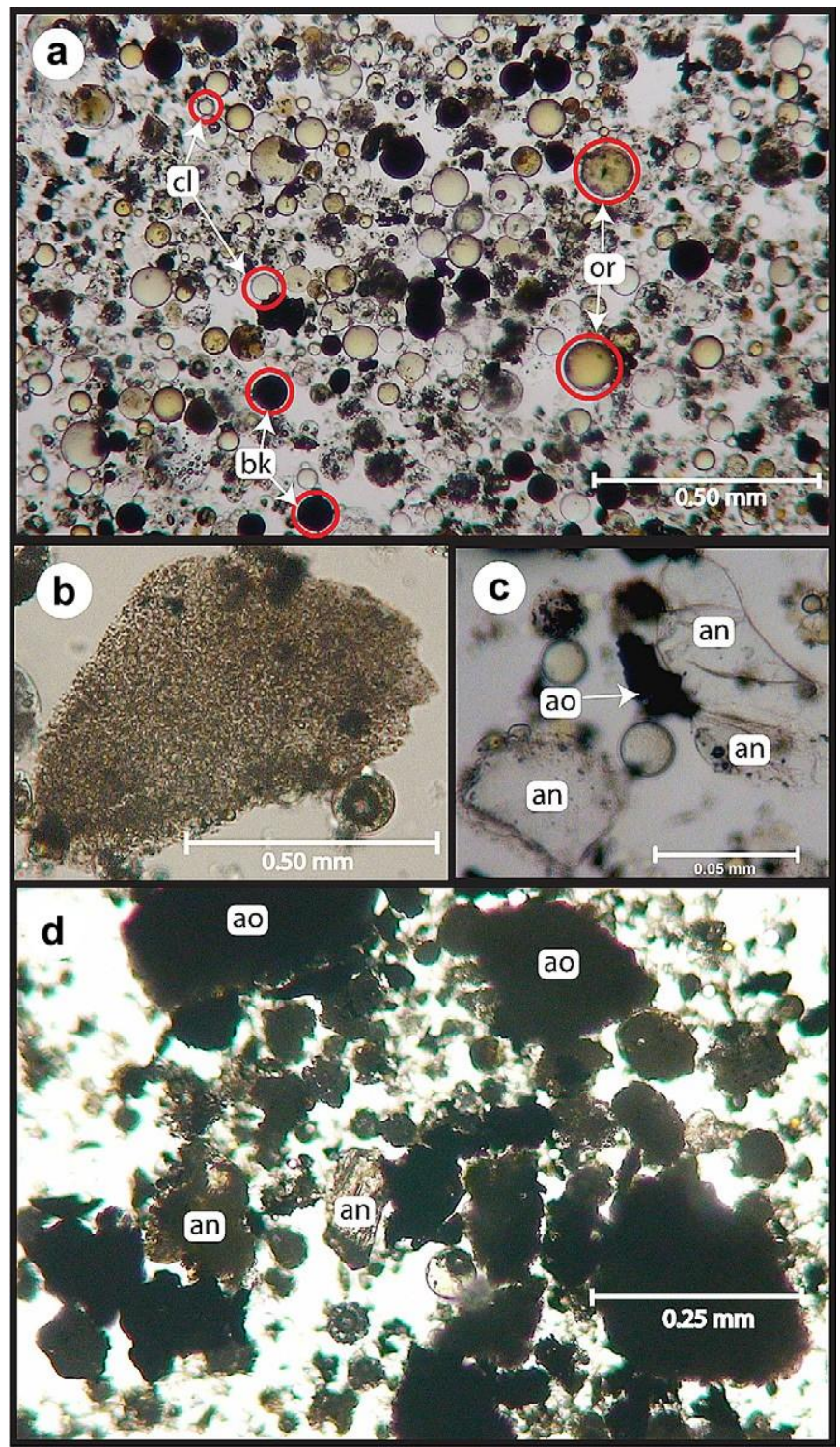

Fig. 2. Light micrographs of Standard ash under polarized light. a. This view is dominated by three types of ash spheres identified by color as clear (cl), orange (or), and black (bk). b. Nonspherical ash includes rounded, vesicular, nonopaque ash. c. Amorphous nonopaque (an) and amorphous opaque (ao) ash with 2 clear spheres. d. Amorphous, opaque (ao) and nonopaque ash (an). All ash morphologies identified in our study were previously described by Fisher et al. (1978). 
larger diameter orange and black-filled spheres (average diameter 8.6 and $9.5 \mathrm{~mm}$ respectively; Fig. 2a). Non-spherical ash is comprised of a diverse group of particles whose morphology was previously described by Fisher et al. (1978). Examples from the Standard ash samples include rounded, vesicular ash (Fig. 2b), amorphous, angular ash (Fig. 2c) and amorphous, opaque ash (Fig. 2d). Particles appearing similar to the non-spherical ash were also observed in riverbed samples but they were not included in our counts of total spherical ash.

Coal fly ash is typically described as heterogeneous with common aggregation of smaller particles to form larger masses (Fig. 2d). The three sample jars containing Standard ash shown in Table 1 were observed to vary by over $10 \%$ in average spherical ash composition, despite TVA's rigorous efforts at homogenization. There is similar variation among slides made from the same sample jar (Table 1).

\subsection{C measurements}

$C_{L F}$ of samples from the river system ranges over two orders of magnitude, from $1.7 \times 10^{-7} \mathrm{~m}^{3} / \mathrm{kg}$ to $1.3 \times 10^{-5} \mathrm{~m}^{3} / \mathrm{kg}$ (Table 2). When the total percent spherical ash is plotted against Log $C_{L F}$ a clear division occurs at $3.0 \times 10^{-6} \mathrm{~m}^{3} / \mathrm{kg}$, above which samples containing greater than $15 \%$ ash from the spill are identified (Group 2; Fig. 3a). The seven samples in Group 1a, with very low $C_{L F}$, have total spherical ash content between 0 and 1.3\%. Group 1a includes samples from areas not impacted by the spill (Emory and Clinch REF) and those collected at depth from cores (Table 2). The trace amounts of ash in these samples, when present include only clear spheres and no orange and black spheres. The ten samples in Group $1 \mathrm{~b}$ have slightly higher $\mathrm{C}_{\mathrm{LF}}$ values between $6.0 \times 10^{-7}$ and $3.0 \times 10^{-6} \mathrm{~m}^{3} / \mathrm{kg}$, and total spherical ash of $0.6 \mathrm{e} 7.2 \%$, with black and orange spheres present in most of these samples. These samples originate at depth in sediment cores or from sites distal to the spill.

Simple least squares linear regression of total percent ash spheres versus $C_{L F}$ for the Bulk samples yields a strong correlation (y $1 / 4$ 1.64E-05(x) p 1.38E-06; $\left.R^{2} 1 / 40.82\right)$ (Fig. 3b). This is the most consistent set of samples within our data; they are all surface sediments that were collected within a short window of time (Fig. 1; Table 2). The ASU samples also shown on Fig. 3b represent a less homogeneous group of samples, collected over a longer time span and including samples from different depths within cores. This may account for the greater variability in the relation between $\mathrm{C}_{\mathrm{LF}}$ and ash for these samples.

Percent mineral grains plotted versus $\log C_{L F}$ shows that the magnetic signal originates from the fly ash and not from minerals eroded from the watershed (Fig. 4a). The high $C_{L F}$ Group 2 samples include Standard ash samples as well as samples from the riverbed with mineral content between 39 and $81 \%$. Samples with greater than $90 \%$ mineral content fall below the threshold of $3.0 \times 10^{-6} \mathrm{~m}^{3} /$ $\mathrm{kg}$ and are in Group 1. In addition, samples with high $\mathrm{C}_{\mathrm{LF}}$ exhibited low frequency dependence (Fig. 4b), as has been previously
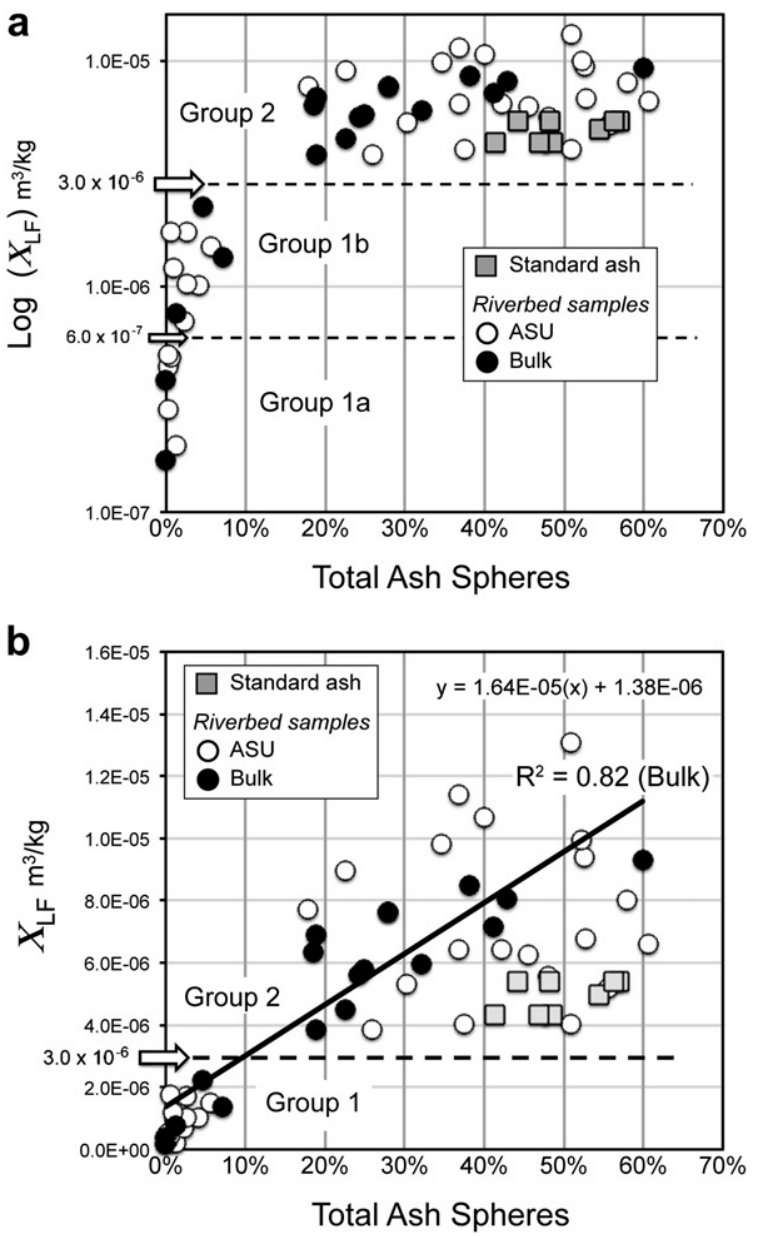

Fig. 3. a. Total ash spheres (\%) versus log CLF. b. Total ash spheres (\%) versus CLF. Simple least squares linear regression is related only for 18 bulk samples.
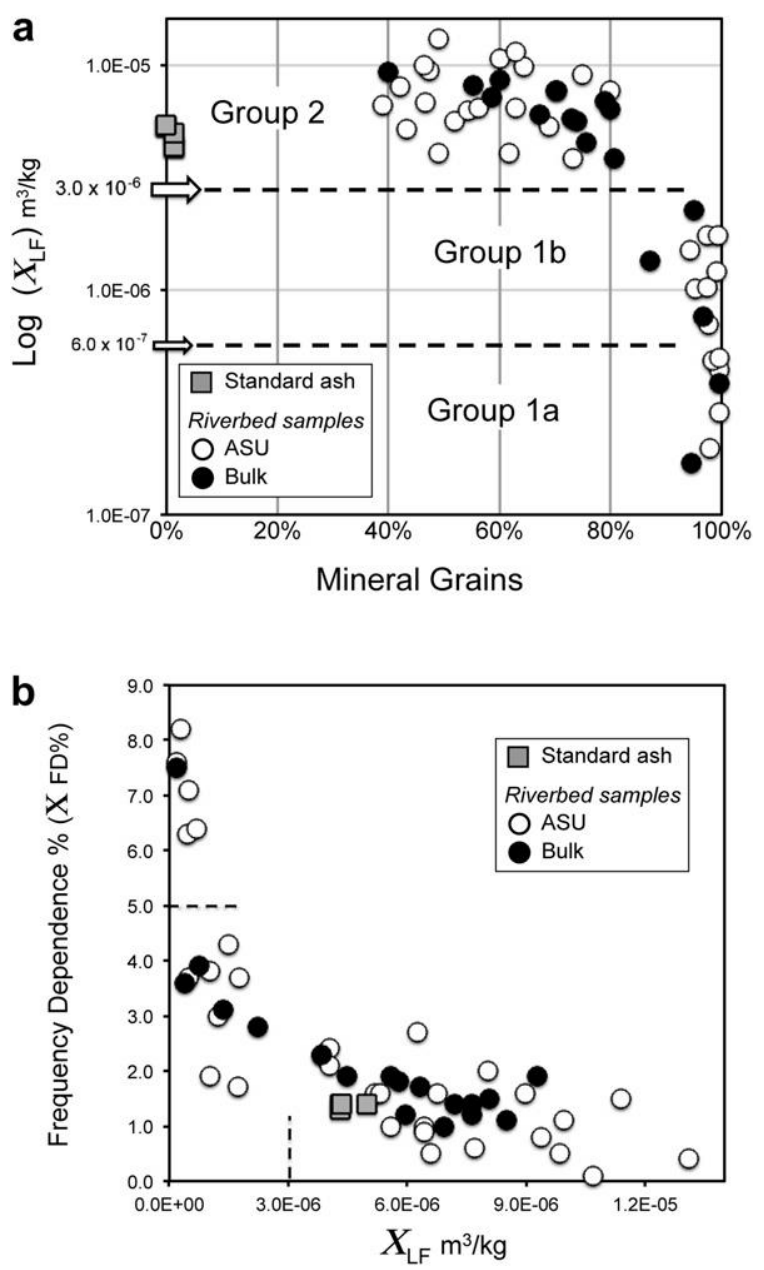

Fig. 4. a. Percent mineral grains versus log $C_{L F}$. b. $C_{L F}$ versus frequency dependence (\%) 
reported for particles of fly ash (Dearing et al., 1996; Magiera et al., 2011). This further indicates that the magnetic carrier is within the fly ash and not the river sediment mixed with it. The highest frequency dependence in the Bulk samples occurs in the Emory and Clinch REF samples, which are located upstream of the spill and contain $0 \%$ ash (Table 2).

Each of the three types of ash spheres is correlated to some extent with $C_{L F}$ (Fig. 5aec). However, these plots do not indicate which type of ash sphere (clear, orange, black) has the greatest influence on $C_{L F}$ because the measured cubes contain mixtures of all ash types. Group 1 clusters tightly around the regression line while Group 2 (ash-contaminated sediments) shows more variability in all sphere types, especially in clear ash spheres (Fig. 5a). The positive correlation is important for predicting total ash content from measurements of $C_{L F}$ on bulk samples, if one sphere type contains more magnetic minerals than the others.

An indication that the black spheres are the primary magnetic carrier controlling the $C_{L F}$ can be observed within Group 1 (Fig. 5d). A plot of $C_{L F}$ versus each of the three types of ash spheres that contain some black ash (including two REF samples) shows a fairly strong correlation between $\mathrm{C}_{\mathrm{LF}}$ and the abundance of black ash spheres $\left(\begin{array}{lll}R^{2} & 1 / 4 & 0.82\end{array}\right)$ compared with clear spheres $\left(\begin{array}{llll}R^{2} & 1 / 4 & 0.15\end{array}\right)$ (Fig. 5d).

Linear regressions between each of the three different sphere types in the Bulk samples show a moderate correlation (of at least $\left.R^{2} 1 / 40.54\right)$ with the ratio of black to clear spheres of $1: 4$, orange to clear of 1:6 and orange to black of 1:1.7. In the Standard
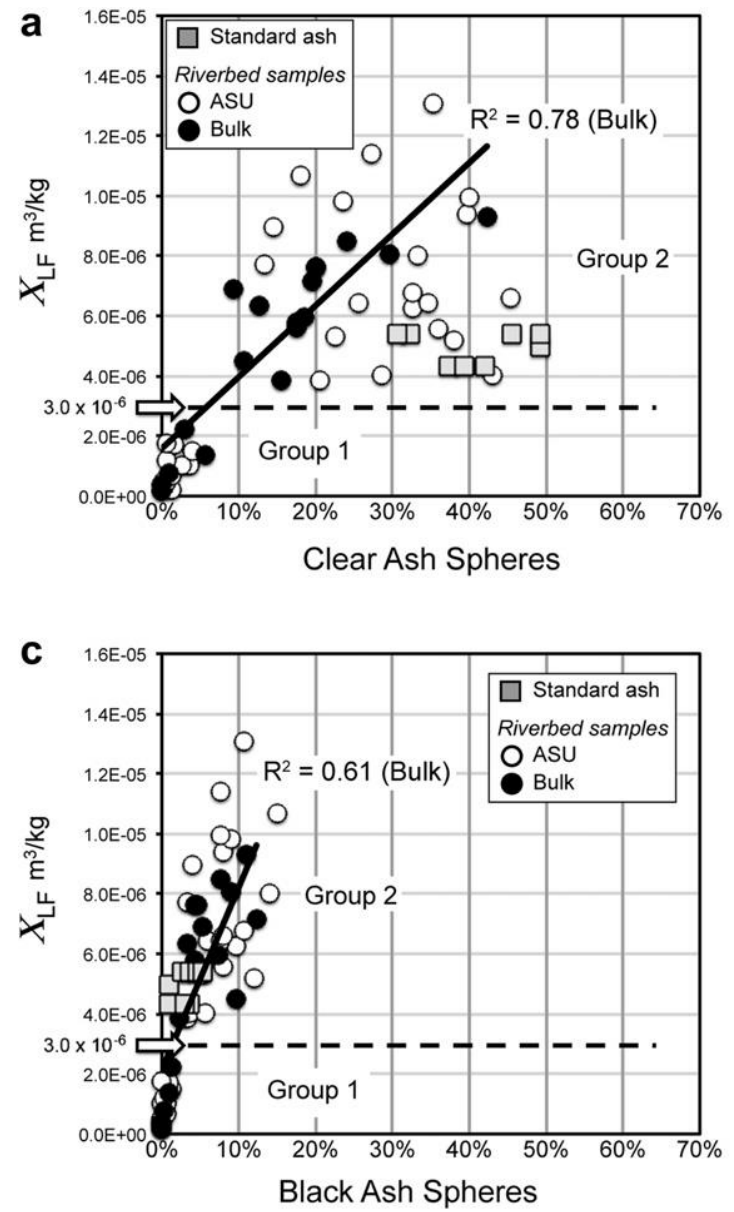

ash samples, clear ash is present in high and variable abundance (30e50\%), black spheres are less than 5\% and orange spheres are less than $10 \mathrm{e} 12 \%$. There is no correlation between the abundance of clear ash and orange and black in samples of Standard ash. However, black versus orange spheres are moderately correlated $\left(R^{2} 1 / 40.52\right)$.

\section{Discussion}

Coal fly ash can be detected as a component of riverbed sediments by $\mathrm{C}$ measurements because ferrimagnetic particles produced by combustion of coal have high $\mathrm{C}$ compared to natural sediments in the Emory and Clinch Rivers. Coal ash samples collected from the storage cell (Standard ash samples) are notably heterogeneous with varying proportions of clear, black, and orange spheres along with a large fraction of non-spherical particles (Fig. 2; Table 1). Fisher et al. (1978) described spheres ranging in color from water-white through yellow and orange to red or brown to opaque. In that work, completely opaque spheres were mostly magnetite or other iron oxides combined with silicates (Fisher et al., 1978). This supports our observation that black spheres seem to have the strongest magnetic signal. Hematite is difficult to detect using only magnetic susceptibility, but it is commonly reddish colored in reflected polarized light (Veneva et al., 2004). We emphasize the importance of the black ash spheres because opaque and colored spheres are described in the literature as containing magnetite or other iron oxides and are likely the ash component with the greatest contributions to
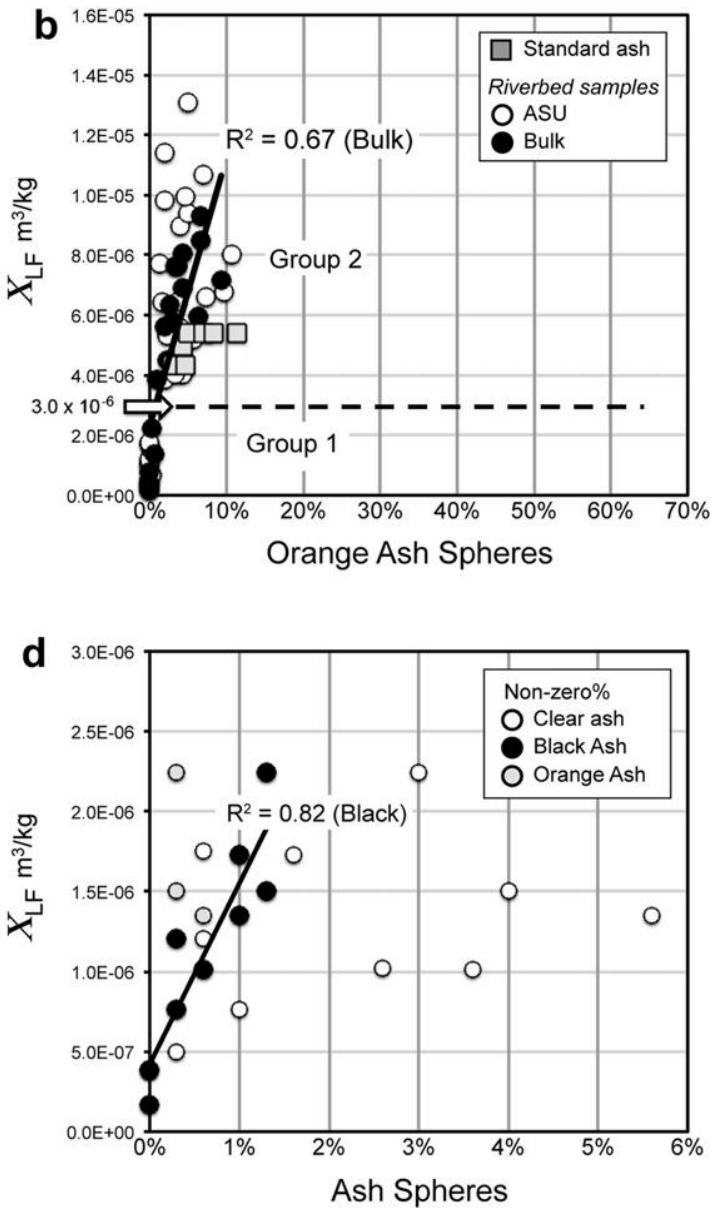

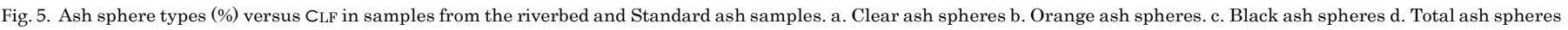
versus $C_{L F}$ in weak magnetic samples (Group 1). 
magnetic susceptibility. We plan to follow our study with additional magnetic and SEM analyses of the Kingston coal fly ash.

\subsection{Assessing the ability of $\mathrm{C}_{L F}$ to detect coal fly ash from the Kingston spill}

To test the applicability of $C_{L F}$ to detect fly ash from the Kingston coal ash spill, we acquired an additional data set of 104 riverbed samples collected during the clean-up and on-going monitoring by the Kingston Ash Recovery Project. Samples contained from 1 to 93\% ash and originated from as far upstream as ERM 6.0 and downstream as CMR 0.0 (Fig. 1). Before we received the samples, total percent ash was determined by a TVA contractor, the RJ Lee Group, following the method described in Section 2.3, except that they included non-spherical ash in their total ash counts. We are able to evaluate the variability between the two counts with respect to $C_{L F}$ because subsamples of the Bulk samples were point counted by both groups (Fig. 6a). Where the point count is very close or overlaps the ash content is likely comprised entirely of spherical ash. The lower correlation in the TVA samples $\left(R^{2} 1 / 40.69\right)$ may reflect the difficulty in distinguishing non-spherical ash from natural minerals in these riverbed samples. The non-spherical ash content in each of these samples was calculated by subtracting the ASU count from the TVA count for each of the 18 samples. The magnetic signal from spherical fly ash is stronger than the signal from non-spherical ash (Fig. 6b).

The TVA data set includes samples that were collected to verify the successful dredging of ash from in the Emory River. It is likely those samples include underlying sediments and soils adjacent to the river so we excluded samples for which $\mathrm{C}_{\mathrm{FD}} \%$ was greater than $5 \%$ from the regression analysis.

The TVA data set is shown along with the Bulk and ASU data sets for reference (Fig. 7). $C_{\text {LF }}$ predicted the ash content of the sediment although the TVA data set has more scatter $\left(R^{2} 1 / 40.67\right)$ and the regression line is shifted to the right compared to the other two data sets. This is primarily due to the inclusion of non-spherical ash by RJ Lee Group resulting in an apparent over prediction of total ash spheres when compared with the Bulk samples.

Some of the scatter observed in the regression plots could originate from differences in the ratio of ash types in samples and their effects on $C_{L F}$. There is a noticeable difference between the ratios of the types of spheres within samples from the riverbed and the Standard ash. This suggests that sorting by the river modifies the ratio of ash types as they are transported downstream. The average diameter of the different colored ash spheres, $5.1 \mathrm{~mm}$ for clear, $8.5 \mathrm{~mm}$ for black and $9.5 \mathrm{~mm}$ for orange, falls within the very fine to fine silt-size range for sedimentary particles.

Although we do not know the density of each ash type, it is reasonable to suggest that if the larger black and orange spheres contain iron oxides in addition to quartz and mullite (Brown et al., 2011) they should be denser than clear spheres. Sorting would occur if the colored spheres are transported together while the smaller, less dense clear spheres are washed away by the same current velocity.

Standard ash samples have a higher percentage of clear ash than the riverbed samples suggesting that fluvial sorting has preferentially transported clear spheres downstream from the spill site. These Standard ash samples fall below and to the right of the regression lines for the other data sets, presumably because of their higher proportion of clear spheres with lower magnetic susceptibility (Fig. 5a). In most cases, samples from the riverbed contaminated by ash from the recent spill have fairly consistent proportions of clear, black and orange ash, which allows for estimating total

percent ash from $C_{L F}$ measurements. Riverbed samples with higher $\mathrm{C}_{\mathrm{LF}}$ than the spilled Standard ash would result from processes that
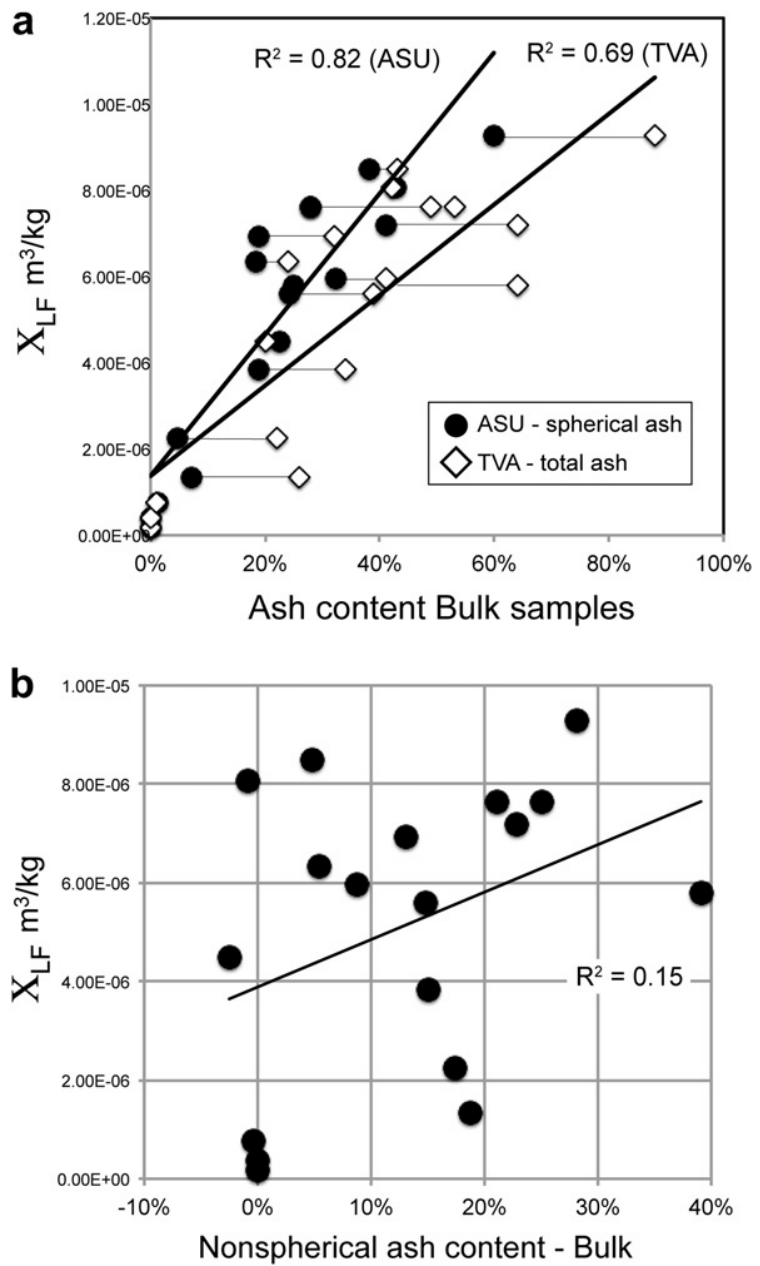

Fig. 6. a. Ash content of bulk samples as point counted by ASU and TVA versus CLF. b. Nonspherical ash content versus $C_{L F}$

concentrate the black spheres with the higher magnetic signal and decrease the proportion of non-spherical ash. In addition to the preferential sorting of orange and black spheres as described above, the irregular morphology and carbonaceous composition of nonspherical particles favor their separation from denser spherical ash particles in the river current thus they would be washed further

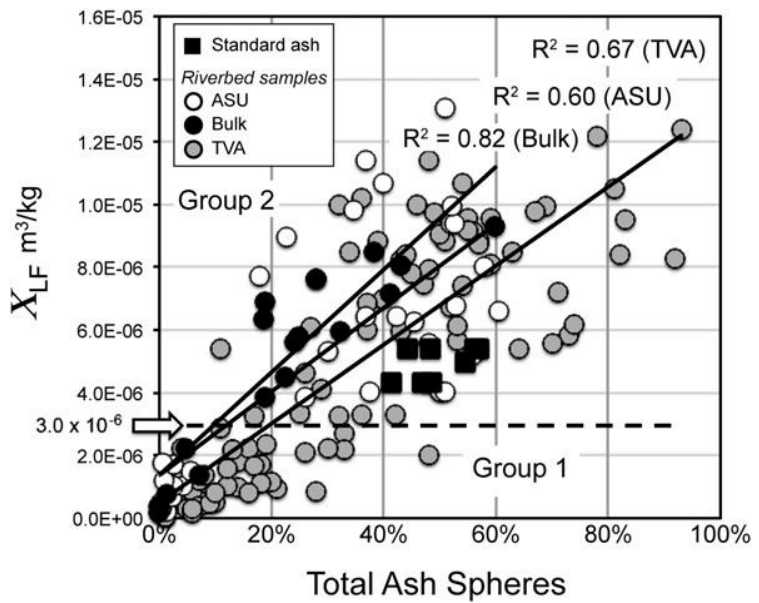

Fig. 7. Total ash spheres versus $C_{L F}$ for Standard ash and all riverbed samples measured in this study, plus a data set collected and point counted by TVA. 
downstream. As the ash from the spill is transported further downstream it will be mixed with native sediments, thus decreasing the $C_{L F}$ of the samples as is shown by the regression line (Fig. 7).

\subsection{Case study: using $\mathrm{C}$ to detect ash within the sediment record}

Since the spill occurred there have been flows in the Emory River greater than $1700 \mathrm{~m}^{3} / \mathrm{s}$ (60 $000 \mathrm{cfs}$ ). Erosion and transport of ash away from the spill site has been modeled for one such event (Scott and Zeller, 2011). As ash is redistributed downstream by high flows and native sediment is transported into this reach of river, ash from the spill can be capped by and mixed with native sediments, effectively archiving ash within the sediment record. This presents two issues for future environmental management; 1) surface samples may not detect ash that is present at depth and, 2) buried ash may later be uncovered and eroded by high discharge events.

Measurements of $\mathrm{C}_{\mathrm{LF}}$ on subsamples from four Emory and Clinch River sediment cores were used to evaluate this method for detecting ash beds within the upper meter of riverbed sediment and for estimating the percent ash in those strata (Figs. 1 and 8). Core a (ERM1 L3_C1) shows a complex stratigraphy with beds containing greater than $50 \%$ ash buried beneath a cap of $10 \mathrm{~cm}$ of gravel (Fig. 8a). The percent ash at depth (determined by point counting) closely follows the $C_{L F}$ measurements. The highest $C_{L F}$ occurred at $56 \mathrm{~cm}$ depth corresponding with a laminated ash interval containing 51\% ash, representing deposits sorted by currents. At $98 \mathrm{~cm}, \mathrm{C}_{\mathrm{LF}}$ is very low, indicating that the sample consists of sediment uncontaminated by ash and the ash content of $<1 \%$ confirms this.
Core b (ERM1 L9_C2) was collected with a gravity corer $600 \mathrm{~m}$ downstream of Core a (Fig. 1). Near the surface the ash content is lower than at depth. The core contains a fining upward ash bed from 15 to $26 \mathrm{~cm}$ depth, with $61 \%$ ash at $19 \mathrm{~cm}$ (Fig. 8b) and with $\mathrm{C}_{\mathrm{LF}}$ closely following $\%$ ash. The absence of ash below an organic mat at $26 \mathrm{e} 30 \mathrm{~cm}$ is indicated by $\mathrm{C}_{\mathrm{LF}}$ of $1.97 \times 10^{-7} \mathrm{mg}^{3} / \mathrm{kg}$ at $39 \mathrm{~cm}$ depth.

Core c (ERM0 L2_C2) shows peaks in $\mathrm{C}_{\mathrm{LF}}$ and percent ash in subsamples at $22 \mathrm{~cm}$ and $29.5 \mathrm{~cm}$ depth (Fig. 8c). Values of $\mathrm{C}_{\mathrm{LF}}$ beneath $38 \mathrm{~cm}$, indicate very low levels of ash confirmed by a point counts of $3 \%$. This sample does not exceed the $C_{L F}$ threshold of samples with greater than $15 \%$ ash from the Kingston spill. It may contain fly ash that was present in the river system prior to the spill.

In the Clinch River, gravity cores either show thin ash beds near the surface or completely lack visible ash. For example, Core d (CRM0 L3_A_C1) was collected from within the channel near the mouth of the Clinch River and has only $5.6 \%$ ash at $6 \mathrm{~cm}$ depth and $<1 \%$ ash deeper (30 and $50 \mathrm{~cm}$ ) in the core (Fig. $8 \mathrm{~d}$ ). All of the subsamples from this core have low $\mathrm{C}_{\mathrm{LF}}$ in Group 1b, suggesting that this core may contain all old reworked ash beneath the surface.

The ability of $C_{L F}$ to detect ash in the sediment record demonstrates the usefulness of $C$ as a technique to assist in the long-term monitoring of ash transport within the fluvial system. The potential for attenuation of ash's magnetic signal over time within the sediment profile is unknown, however a laboratory study by Kapi a et al. (2000) determined that $C$ of fly ash was stable under different chemical conditions in a soil (including leaching in acid and neutral solutions). Magiera et al. (2002) were able to measure seasonal variations in C of Lake Zywiec bottom sediments caused by fluctuations in fly ash input. This further highlights the usefulness of $C$ in estimating coal fly ash concentrations in the natural

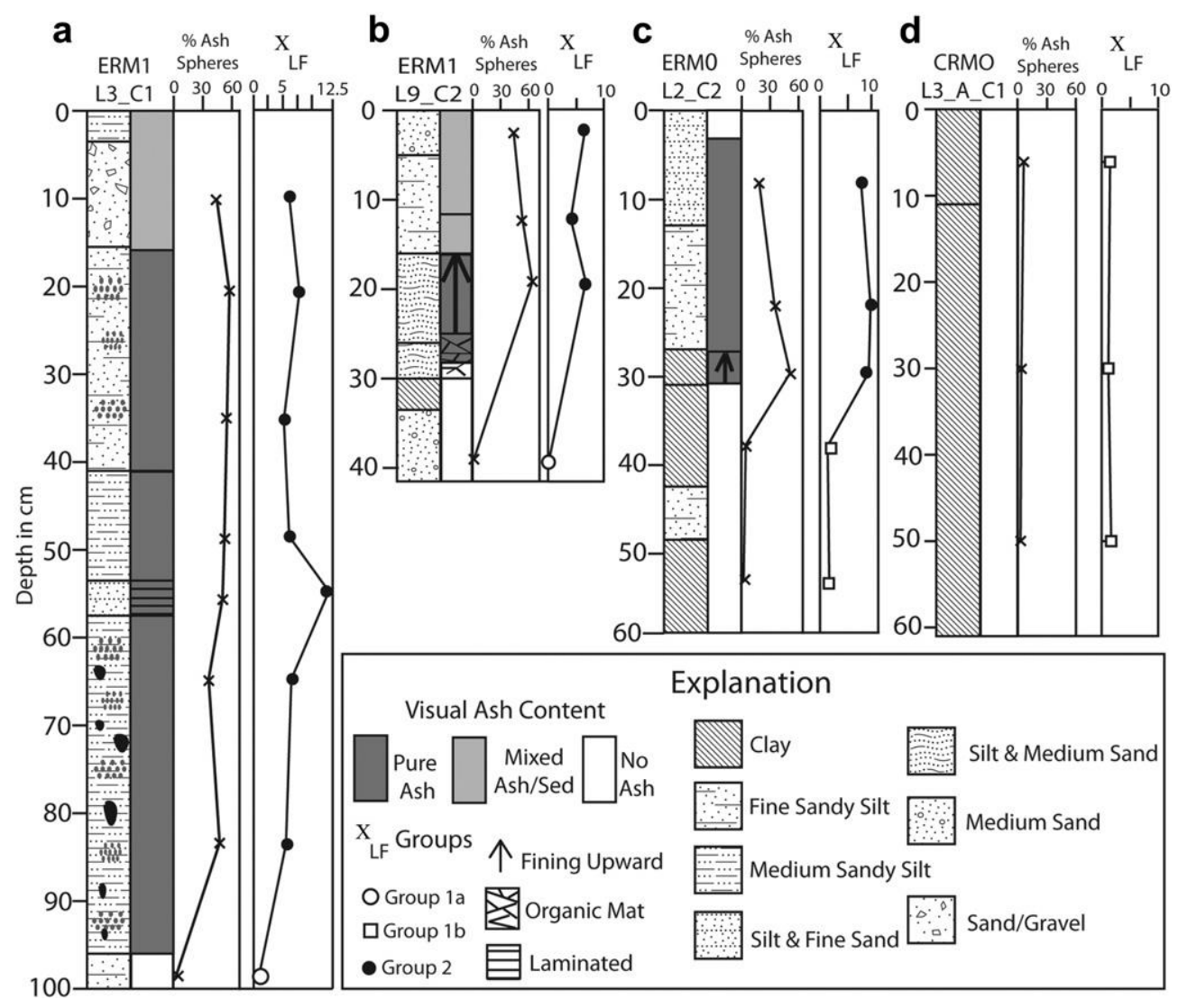

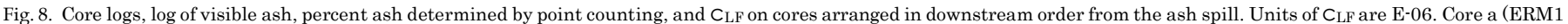
L3_C1), core b (ERM1 L9_C2), core c (ERM0 L2_C2) and core d (CRMO L3_A_C1) are located on Fig. 1. 
environment over long time periods. In addition, measurements of $C$ are rapid, inexpensive, reliable, and allow collection of large data sets necessary for statistical and graphical interpretation of the distribution of ash concentrations (Petrovský et al., 2000).

\section{Conclusions}

- Coal fly ash is a heterogeneous, fine-grained material composed, in part of magnetic minerals formed during combustion. $C_{L F}$ can be used to detect the ash spilled into the Watts Bar Reservoir system at Kingston Tennessee as it is transported by the fluvial system.

- $C_{\mathrm{LF}}$ greater than $3.0 \times 10^{-6} \mathrm{~m}^{3} / \mathrm{kg}$ indicates the presence of more than $15 \%$ ash spheres from the Kingston coal ash spill in samples of riverbed sediment.

- A storng correlation between $C_{L F}$ and total percent total ash spheres $\left(R^{2} 1 / 40.82\right)$ for surface sediments enables estimation of percent ash from $C_{L F}$ measurements on bulk sediment samples.

- Point counting under an optical polarizing microscope shows coal fly ash from the Kingston Fossil Plant is heterogeneous, comprised of an average of about $50 \%$ clear, orange, and black spheres and about 50\% non-spherical particles.

- Samples from the ash storage cell have an abundance of clear spheres and paucity of black and orange spheres. In riverbed samples, a relatively constant ratio between the three sphere types occurs indicating a modification of this distribution by fluvial processes during transport.

- Black spherical ash appears to be the primary source of the magnetic signal for riverbed samples contaminated by ash although other ash spheres contribute to a lesser extent.

- This study illustrates the usefulness of C measurements for tracking coal fly ash within the Emory and Clinch River system as it is reworked and incorporated into the sediments by fluvial processes. This rapid, nondestructive method is quantitative and is relatively inexpensive in comparison to the other methods of quantifying ash in sediments.

\section{Acknowledgments}

Daniel Bochicchio, Aaron Pruitt, and John Russell assisted with the laboratory analyses at Appalachian State University. TVA provided logistical support in the field for sample collection. Neil E. Carriker, William J. Rogers and Patrick Lee kindly provided the Standard ash samples, the Bulk sample set, and riverbed samples (TVA) that were point counted by RJ Lee Group so that we could increase the sample size of our study. This research was funded by National Science Foundation, Award EAR-0929154 to Roy Sidle, lead PI and by the TVA Kingston Ash Recovery Project. We also thank three anonymous reviewers for helpful comments on this manuscript.

\section{References}

Bednar, A.J., Chappell, M.A., Seiter, J.M., Stanley, J.K., Averett, D.E., Jones, W.T., Pettway, B.A., Kennedy, A.J., Hendrix, S.H., Steevens, J.A., 2010. Geochemical investigations of metals release from submerged coal fly ash using extended elutriate tests. Chemosphere $81,1393 \mathrm{e} 1400$.

Blundell, A., Hannam, J.A., Dearing, J.A., Boyle, J.F., 2009. Detecting atmospheric pollution in surface soils using magnetic measurements: a reappraisal using an England and Wales database. Environmental Pollution 157, 2878e2890.

Booher, H.B., Martello, D.V., Tamilia, J.P., Irdi, G.A., 1994. Microscopic study of spheres and microspheres in fly ash. Fuel 73, 205e213.

Brown, P., Jones, T., BéruBé, K., 2011. The internal microstructure and fibrous mineralogy of fly ash from coal-burning power stations. Environmental Pollution 159, 3324e3333.

Bryan Jr., A.L., Hopkins, W.A., Parikh, J.H., Jackson, B.P., Unrine, J.M., 2012. Coal fly ash basins as an attractive nuisance to birds: parental provisioning exposes nestlings to harmful trace elements. Environmental Pollution 161, 170e177.
Butler, R.F., 1992. Paleomagnetism: Magnetic Domains to Geologic Terranes. Blackwell Scientific Publications, Boston, pp. 1 e317.

Carriker, N., Yankee, D., Sherrard, R., Jones, D., Young, S., Clay, P.,, 2011. Integrated ecological research e TVA Kingston Ash Recovery Project. Abstracts: TVAKingston Fly Ash Release Environmental Research Symposium, August 2e3, 2011 , p. 1.

Chaddha, G., Seehra, M.S., 1983. Magnetic components and particle size distribution of coal fly-ash. Journal of Physics D-Applied Physics 16, 1767e1776.

Dearing, J.A., Dann, R.J.L., Hay, K., Lees, J.A., Loveland, P.J., Maher, B.A., 1996. Frequency-dependent susceptibility measurements of environmental materials. Geophysics Journal International 124, 228e240.

Dearing, J.A., 1999. Environmental Magnetic Susceptibility, Using the Bartington MS2 System. Bartington Instruments, Ltd., British Library London, 54 pp.

Dreimanis, A., Vagners, U.J., 1971. Bimodal distribution of rock and mineral fragments in basal tills. In: Goldthwait, R.P. (Ed.), Till e a Symposium. Ohio State University Press, Columbus, Ohio, pp. 237e250.

Fisher, G.L., Chang, D.P.Y., Brummer, M., 1976. Fly ash collected from electrostatic precipitators: microcrystalline structures and the mystery of the spheres. Science 192, 553e555.

Fisher, G.L., Prentice, B.A., Silberman, D., Ondov, J.M., Blermann, A.H., Ragaini, R.C., McFarland, A.R., 1978. Physical and morphological studies of size-classified coal fly ash. Environmental Science and Technology 12, 447e451.

Flanders, P.J., 1994. Collection, measurement, and analysis of airborne magnetic particulates from pollution in the environment (invited). Journal of Applied Physics 75, 5931e5936.

Flanders, P.J., 1999. Identifying fly ash at a distance from fossil fuel power stations. Environmental Science and Technology 33, 528e532.

Hanesch, M., Scholger, R., 2002. Mapping of heavy metal loadings in soils by means of magnetic susceptibility measurements. Environmental Geology 42, 857 e870.

Jankowski, J., Ward, C.R., French, D., Groves, S., 2006. Mobility of trace elements from selected Australian fly ashes and its potential impact on aquatic ecosystems. Fuel $85,243 e 256$

Jordanova, D., Hoffmann, V., Fehr, K.T., 2004. Mineral magnetic characterization of anthropogenic magnetic phases in the Danube river sediments (Bulgarian part). Earth and Planetary Science Letters 221, 71e89.

Kapi ka, A., Jordanova, N., Petrovský, E., Ustjak, S., 2000. Magnetic stability of power-plant fly ash in different soil solutions. Physics and Chemistry of Earth $25,431 \mathrm{e} 436$.

Kutchko, B.G., Kim, A.G., 2006. Fly ash characterization by SEM-EDS. Fuel 85, $2537 \mathrm{e} 2544$.

Li, F., Li, G., Ji, J., 2011. Increasing magnetic susceptibility of the suspended particles in Yangtze River and possible contribution of fly ash. Catena 87, 141e146.

Magiera, T., Strzyszcz, Z., Kostecki, M., 2002. Seasonal changes of magnetic susceptibility in sediments from Lake Zywiec (South Poland). Water, Air, and Soil Pollution 141, 55e71.

Magiera, T., Jablonska, M., Strzyszcz, Z., Rachwal, M., 2011. Morphological and mineralogical forms of technogenic magnetic particles in industrial dusts. Atmospheric Environment 45, 4281e4290.

Norton, G.A., Markuszewski, R., Shanks, H.R., 1986. Morphological and chemical characterization of iron-rich fly ash fractions. Environmental Science and Technology 20, 409e412.

Petrovský, E., Kapi ka, A., Jordanova, N., Knab, M., Hoffmann, V., 2000. Low-field magnetic susceptibility: a proxy method of estimating increased pollution of different environmental systems. Environmental Geology 39, 312e318.

Presuel-Moreno, F.J., Sagüés, A.A., 2009. Bulk magnetic susceptibility measurements for determination of fly ash presence in concrete. Cement and Concrete Research 39, 95e101.

Querol, X., Parés, J.M., Planà, F., Fernández-Turiel, J.L., López-Soler, A., 1994. Fly ash content and distribution in lake sediments around a large power station: inferences from magnetic susceptibility analysis. Environmental Geochemistry and Health 16, 9e18.

RJ Lee Group, 2010. Standard Operating Procedure for Determination of Fly Ash in Bulk Samples by Polarized Light Microscopy, OPT 023, 9 pp.

Rogers, W., 2012. Personal Communication.

Ruhl, L., Vengosh, A., Dwyer, G.S., Hsu-Kim, H., Deonarine, A., 2010. Environmental impacts of the coal ash spill in Kingston, Tennessee: an 18-month survey. Environmental Science and Technology 44, 9272e9278.

Ruhl, L., Vengosh, A., Dwyer, G.S., Hsu-Kim, H., Deonarine, A., Bergin, M., Kravchenko, J., 2009. Survey of the potential environmental and health impacts in the immediate aftermath of the coal ash spill in Kingston, Tennessee. Environmental Science and Technology 43, 6326e6333.

Scott, S., Zeller, C., 2011. 2D sediment transport simulation to support the monitored natural recovery process for Watts Bar reservoir. Abstracts: TVA-Kingston Fly Ash Release Environmental Research Symposium, August 2e3, 2011, p. 15.

Sokol, E.V., Kalugin, V.M., Nigmatulina, E.N., Volkova, N.I., Frenkel, A.E., Maksimova, N.V., 2002. Ferrospheres from coal fly ashes from Chelyabinsk coals: chemical composition, morphology and formation conditions. Fuel 81, $867 \mathrm{e} 876$.

TDEC, 2002. Emory River Watershed (06010208) of the Tennessee River Basin Water Quality Management Plan, Chapter 2, Description of the Emory River Watershed. http://www.tn.gov/environment/watersheds/.

TDEC, 2006. Lower Clinch River Watershed (06010207) of the Tennessee River Basin Watershed Water Quality Management Plan, Chapter 2, Description of the Lower Clinch River Watershed. http://www.tn.gov/environment/watersheds/. 
Tennessee Valley Authority, 2009. Corrective Action Plan for the TVA Kingston Fossil Plant Ash Release. http://www.tva.gov/kingston/admin_record/pdf/G/G4.pdf.

Thompson, R., Oldfield, F., 1986. Environmental Magnetism. Allen and Unwin, London, pp. 1e227.

Veneva, L., Hoffmann, V., Jordanova, D., Jordanova, N., Fehr, Th, 2004. Rock magnetic, mineralogical and microstructural characterization of fly ashes from Bulgarian power plants and the nearby anthropogenic soils. Physics and Chemistry of the Earth 29, 1011e1023.
Verosub, K.L., Roberts, A.P., 1995. Environmental magnetism: past, present, and future. Journal of Geophysical Research 100, 2175e2192.

Wadge, A., Hutton, M., Peterson, P.J., 1986. The concentrations and particle size relationships of selected trace elements in fly ashes from U.K. coal-fired power plants and a refuse incinerator. The Science of the Total Environment 54, 13e27.

Zyryanov, V.V., Petrov, S.A., Matvienko, A.A., 2011. Characterization of spinel and magnetospheres of coal fly ashes collected in power plants in the former USSR. Fuel 90, 486e492. 